\title{
Risk Management Practices to Strengthen Public Sector Accountability
}

\author{
Bebe Abu Bakar, Siti Zaleha Abdul Rasid*, Adriana Mohd Rizal and \\ Shathees Baskaran
}

\begin{abstract}
Manuscript type: Research paper

Research aims: Risks can challenge the public sector's service delivery system and growth sustainability. While the notion of modern accountability demands some display of risk management (RM) initiatives, less attention has been given to the impact of RM practices on organisational accountability as well as the effect of performance measurement system (PMS) use on RM practices. Drawing from the resource-based view, this study attempts to investigate the predictive effect of RM practices and (PMS) use on accountability by using a mediation framework.

Design/Methodology/Approach: Cross-sectional survey is applied to collect data from the top management of the Malaysian Federal Statutory Bodies (FSBs). The research framework is tested by analysing the data of 110 Malaysian FSBs through the structural equation modelling technique (PLS-SEM).

Research findings: The result of the study demonstrates that PMS use for monitoring and PMS use for attention-focusing have a significant
\end{abstract}

\footnotetext{
* Corresponding author: Siti Zaleha Abdul Rasid is an Associate Professor at Azman Hashim International Business School (AHIBS), Universiti Teknologi Malaysia, Kuala Lumpur, Malaysia. E-mail: szaleha@ibs.utm.my

Bebe Abu Bakar is an Accountant at Office of the Bursar, Universiti Teknologi Malaysia, Johor, Malaysia. E-mail: bebe@utm.my

Adriana Mohd Rizal is a Senior Lecturer at Azman Hashim International Business School (AHIBS), Universiti Teknologi Malaysia, Kuala Lumpur, Malaysia. E-mail: adriana.kl@utm.my Shathees Baskaran is a Senior Lecturer at Azman Hashim International Business School (AHIBS), Universiti Teknologi Malaysia, Kuala Lumpur, Malaysia. E-mail: shathees@ibs.utm.my

Acknowledgement: This research was funded by the Ministry of Education through the Fundamental Research Grant Scheme (FRGS) (Vote No. R.K 130000.7863.4F226).
}

https://doi.org/10.22452/ajba.vol12no1.1 
positive effect on RM practices. Additionally, RM practices mediate the relationship between PMS use and accountability.

Theoretical contribution/Originality: This paper is among the few to assess the effect of PMS use on RM practices and to determine the mediation effect of RM practices on the relationship between PMS use and accountability.

Practitioner/Policy implication: These findings provide valuable insights for authorities in the public sector on the ways to enhance public sector governance through new mechanisms of accountability such as RM practices.

Research limitation/Implication: This study uses a non-probability sampling. Considering the difference in design and use of control systems among the different sectors or industries, the results may not be generalised to other populations. However, the outcome of this study suggests that RM practices do strengthen public sector accountability with the appropriate use of the PMS.

Keywords: Risk Management, Performance Measurement System, Accountability, Public Sector

JEL Classification: M41

\section{Introduction}

Risk management (RM) is an integral component of good management. Primarily, it is concerned with the achievement of strategic objectives (Woods, 2008). Due to the uncertainties and intense competition impacted by globalisation and market liberalisation (Azizan \& Lai, 2013), organisations around the world are exposed to various types of risks which need to be managed. RM has been defined by the Malaysian Standard of ISO 31000:2010 as coordinated activities which direct and control organisations with regards to risk. RM which involves the identification and mitigation of risks in accordance to the organisation's capacity is crucial for strategic planning, control and decision making (Mikes, 2009). RM could also lead to better project management, effective use of resources and better service delivery (Collier, Berry, \& Burke, 2006).

The Malaysian Federal Statutory Bodies (FSBs) are not excluded from risks which affect the effectiveness and efficiency of their service delivery system. Risks can affect FSBs seriously by challenging their growth sustainability. Instances of the increasing trend of irregularities, non-compliance to regulation and mismanagement of government assets are deteriorating public sector accountability while the existing 
mechanisms of public sector accountability are being challenged; it is eroding public trust and confidence (Siddiquee, 2006). Audit findings for the past few years have uncovered 102 cases of mismanagement and financial irregularities (National Audit Department, 2011; 2012; 2013; 2014). The latest financial management and internal control of the FSBs have revealed that 77 per cent of the rotationally audited agencies in 2013 had been ranked below excellent level (four stars) in their rankings (National Audit Department, 2013). Even though this showed slight improvement when compared to the 2011 percentage of 89 per cent, prolonged weaknesses have eroded public trust in the public sector agencies. This phenomenon has accelerated the challenges for FSBs to sustain their accountability, particularly in demonstrating excellent results and value-for-money. In this regard, sophisticated tools or strategies are needed to enforce responsible administrative behaviours (Siddiquee, 2006) so as to regain public confidence. Studies (Collier \& Woods, 2011; Leung \& Isaacs, 2008) have proposed that RM practices could be used to address issues related to the FSB's accountability in delivering better results, value-for-money and also control purposes. To stay abreast with competition among other sectors, there has been increasing initiatives to mitigate risks through RM control. However, less attention has been given to examine how RM practices can vary in different situations. The outcome of such investigations can enable FSBs to strengthen their accountability.

Accountability relates to the provision of visibility and transparency of organisational activities and the promotion of appropriate behaviours which ultimately lead to improved organisational performance (Dubnick, 2005). Poor accountability is attributed to the lack of proper disclosure and transparency (Bakar \& Saleh, 2015). Existing accountability literature (Abdali, Hourani, Abuerrub, \& Shambour, 2013; Bolton, 2003; Halachmi, 2002; Hoque, 2008; Kloot, 2009; Saliterer \& Korac, 2013; Tan, 2014) noted that PMS is an important factor which affects public sector accountability. At the same time, Said, Abidin and Nassir (2014) also argued that mission based management practices are necessary to demonstrate high levels of accountability. The fundamental risks faced by public sector agencies is the reason triggering the various recommended measures or mechanisms for monitoring accountability. Nonetheless, these mechanisms also need to be based on good governance principles (Witthoft, 2003). To deal with this, the RM process has to be established within an institution so as to dilute the excessive concentration of power that is in the hands of the management. Undeniably, 
RM practices are the integral part of the mission-based management system. Previous works (Arena, Arnaboldi, \& Azzone, 2010) have observed that RM practices were rationalised either by organisational compliance or performance. Nevertheless, insistent demands from the public for a more transparent and accountable gov-ernment have pressured many countries to reform their public sector agencies. Taking Malaysia as a country with the intention to regain public confidence and trust, it appears that the current Malaysian government is imitating other developed countries or advanced nations in its effort to enhance its accountability (Bakar, Saleh, \& Mohamad, 2011). The public's call for better governance requires serious government concerns even though it may be claimed that the delivery of public services has been progressively improved through good organisational practices such as the open and transparent procurement activities (Rahman, Ab Rahman, Azhar, Omar, \& Said, 2015). While the notion of modern accountability in the public sector demands some manifestations of the RM initiatives (Nyland \& Petterson, 2015), previous studies (Baldry, 1998; Azizan \& Lai, 2013) have totally ignored accountability as one of the rationality of $\mathrm{RM}$ in the public sector. Therefore, a study on how the emphasis for RM practices can affect organisational accountability is necessary.

Studies investigating factors related to the usage and design of RM are many but their determinants are clustered around accounting ratios, corporate governance structure and company characteristics which seem more suitable for private sector organisations. These studies (Azizan \& Lai, 2013; Collier \& Woods, 2011; Woods, 2009) seemed to ignore the context and the institutional setting in which different organisations operate. Alternatively, an organisation's objectives are assessed by defining performance measures which are associated with each objective. These measures helped management to focus on what they are trying to control. Since RM is also about achieving objectives, the measurable performance measures provide input and become targets for RM success (Chapman, 2006; Loosemore, Raftery, \& Reilly, 2006). However, less attention has been given to the variation of RM practices due to the effects of its proposed driver, the performance measurement system (PMS) used. Specifically, both the strategic information produced by the PMS and the RM system are considered as resources (intangible assets) under the resource-based view (RBV). They could contribute to superior performance and a competitive advantage (Barney, 1991).

The variation in RM practices include different emphasis placed within the RM processes which consists of risk identification and 
risk assessment. Therefore, based on the RBV, this research will fill the theoretical gap by investigating the effect of the different drivers (PMS use for monitoring and PMS use for attention-focusing) on RM practices and the impact of RM practices on accountability. The purpose of this study is to investigate the predictive effects of the PMS use and RM practices on accountability. The mediation framework is applied in the context of FSBs of Malaysia. However, the population of the study excludes other public sectors including the federal ministries, state government and local authorities as well as government-linked companies and government subsidiaries which are incorporated under the Companies Act 1965 that has a small number in population and do not have a RM framework or is still planning to have one.

This study contributes to the literature by addressing the importance of RM practices for FSBs in Malaysia, highlighting the significance of risks tolerance in strategic decision making for sustainability. The findings are aimed at improving the RM practices and accountability of the public sector by expanding their knowledge of RM practices, thereby offering solutions. The outcome generated could influence policy in a particular area, which might otherwise remain ignored despite its significance. At present, the debate on the contribution and variance of RM practices are focussed on the private sector, hence more attention needs to be focussed on the public sector. It is hoped that this study will contribute to raising the awareness and the understanding of the potentials of RM by highlighting their relevance to risk related problems and issues in the public sector.

The remainder of this paper is organised as follows: Section 2 reviews the literature on accountability, RM practices and RM practices in the public sector and PMS use. Section 3 discusses the research hypotheses derived from the proposed conceptual framework and the underpinning theories. The section also highlights the need to examine various variables within a mediation framework of accountability. Section 4 describes the research methodology while Section 5 discusses the statistical results. Finally, Section 6 concludes the study by providing the research implications.

\section{Literature Review}

\subsection{Accountability}

There are various meanings attached to accountability but it basically means the need to give reasons for certain actions taken to those who 
deserve clarification (Parker \& Gould, 1999). Previous studies (Broadbent, Dietrich, \& Laughlin, 1996; Sinclair, 1995; Gray \& Jenkins, 1993) stated that accountability is the delegation of power by stakeholders (principal) to managers (agents). Traditional accountability begins with Stewart's (1984) ladder of accountability which varies from probity and legal accountability to programme, performance, process and policy accountability. Subsequently, Sinclair (1995) revealed five distinct dimensions of accountability which include managerial, public, fiduciary, political and personal accountability. Under public accountability, the public administrators and agencies are required to respond to public interest. This accountability can be classified into two components: accountability for good administration and administrative accountability (Stewart, 1984). In the public sector, accountability mechanisms are considered in the context of governance (Almquist, Grossi, van Helden, \& Reichard, 2013) which include organisational structure and tools. In the present study, accountability refers to "governance arrangements and practices" which are outlined to furnish visibility of results and compliance with rules and regulations to stakeholders.

To ensure public sector accountability, managers need to equip themselves with the ability to identify and manage risks and opportunities (Queensland Treasury, 2011). However, very few studies have ventured into examining the impact of RM practices on organisational accountability. Nonetheless, the notion of modern accountability in the public sector also known as result-based accountability, demands some demonstration of risk management initiatives (Nyland \& Petterson, 2015; Spira \& Page, 2003). There was even a call for more frontier research in governance and accountability so as to consider RM as a mechanism for accountability (Brennan \& Solomon, 2008). This study aims to fill the theoretical gap by empirically examining the impact of RM practices on organisational accountability; it also aims to explain the impact from the RBV perspective (Wang, Barney, \& Reuer, 2003; Andersen, 2008).

\subsection{Risk Management Practices}

Risk issues have received critical attention as they are economically costly. Considerable attention was given to risk issues after various global man-made disasters. Risks are uncertain future events which can impinge on an organisation's effort towards the achievement of objectives (Sobel \& Reding, 2004). Risks can result in negative or positive consequences (Burtonshaw-Gunn, 2009; Drew, Kelly, \& 
Kendrick, 2006; Tang, 2006). Initially, risk was denoted with negative effects and described as a threat of potential losses. The aim was to minimise potential losses and to avoid risky actions which would lead to instability for the organisation (Collier, 2009). Subsequently, risk was also referred to with positive effects. It was retained so as to take advantage of the risk that would lead to the organisation's benefit (Collier, 2009). Most recently, risk was also defined as the "effect of uncertainty on objectives" (MS ISO 31000:2010).

Different types of industries design different control systems to accommodate their needs and this causes systematic variations in the type of RM framework and stages of RM practised (Mikes, 2009). Some organisations invest in sophisticated RM system, some have developed a complete RM framework while others practise RM through a partial framework (Paape \& Speklé, 2012). Despite the increasing investigations done on RM adoption and usage, very few studies (Mikes \& Kaplan, 2014; Al-Tamimi \& Al-Mazrooei, 2007) examine or compare the different processes of the RM practices. Therefore, it is worth examining the different processes of RM practices in order to examine the variations of RM practices within the FSBs. With reference to the MS ISO 31000:2010, this study examines the three main processes of RM which include risk identification, risk assessment and risk monitoring. The first dimension of RM practices - risk identification, is concerned with recognising risk sources and their causes as well as future consequences (MS ISO 31000:2010). The purpose is to generate a comprehensive list of risk that could distort the achievement of objectives. This process is critical for ensuring that all risks are included in further analysis. Events identified from this process are differentiated between positive (opportunities) and negative (risks) impacts. Normally, the tools and techniques employed for risk identification suits the organisation's objectives (MS ISO 31000:2010). The techniques include interactive methods such as face-toface interviews and workshops or self-assessment techniques including reviewing historical data and personal experiences (Mikes \& Kaplan, 2014). The risk identification techniques are applied with varying frequencies (COSO, 2004), depending on the velocity of risk evolution (Mikes \& Kaplan, 2014).

The next dimension is risk assessment which includes risk analysis and risk evaluation. Basically, risk analysis envisions risk by determining the organisation's risk levels (MS ISO 31000:2010). Risk analysis considers the causes and sources of risk as well as the likelihood of occurrences and the impact of risk on the achievement of objectives. 
The consequences and likelihood are combined to determine the level of risk. In addition, risk is regarded as quantifiable (Loosemore et al., 2006) where statistical data could be available for evaluation (Merna \& Al-Thani, 2005). Risk assessment techniques can be qualitative or quantitative or both (Mikes, 2009; Subramaniam, Collier, Phang, \& Burke, 2011). More sophisticated risk assessment methods include stochastic modelling (Subramaniam et al., 2011). As part of risk assessment, the risks will be evaluated to determine its significance for it to be acceptable or tolerable. It compares the organisation's risk level with the risk criteria established. The comparison exercise leads to decisions about: (1) risk treatment plan, (2) further analysis, or (3) maintaining existing controls (MS ISO 31000:2010). The following dimension is risk monitoring which actually monitors and reviews the RM process. This process involves continual observations of any variance - from the target to regular checking and surveillance (MS ISO 31000:2010). In this study, the risk monitoring and reviewing process (Al-Tamimi \& Al-Mazrooei, 2007) looks at all aspects of RM for the purpose of: (1) assuring the effectiveness of RM control, (2) evaluating the effectiveness of risk assessment, (3) monitoring changes in risk criteria, and (4) revising risk treatment or priorities (MS ISO 31000:2010).

Literature on RM revealed that researchers have intensively investigated the determinants and drivers of RM in different parts of the world. For example, in the United States, factors including chief risk officer (CRO), board composition and independence, financial distress and leverage, institutional ownership, firm size, industry affiliation, risk type, environmental uncertainty, firm complexity and industry competition were found to have effect on the stage of RM adoption. This phenomenon was also prevalent in different industries (Beasley, Clune, \& Hermanson, 2005; Colquitt, Hoyt, \& Lee, 1999; Gordon, Loeb, \& Tseng, 2009; Liebenberg \& Hoyt, 2003; Mikes \& Kaplan, 2014; Pagach \& Warr, 2011). In the context of Malaysia, among the factors which influenced RM practices were CRO (Saeidi, Sofian, Rasid, \& Saeid, 2012; Daud \& Yazid, 2009; Daud, Yazid, \& Hussin, 2010), board of directors composition, pressure from regulations and corporate governance (Hudin \& Hamid, 2014; Manab, Kassim, \& Hussin, 2010), financial leverage and external auditor (Golshan \& Rasid, 2012); technology advancement, good business practice and decision making (Manab et al., 2010) and organisational trust (Saeidi et al., 2012). However, previous literature tends to focus on the usage and design of risk management and the factors affecting them. Very little attention is given to the effect 
of PMS use as the driver influencing the initiation of different processes of RM practices.

A considerable number of studies (Andersen, 2008; 2009; Baxter, Bedard, Hoitash, \& Yezegel, 2013; Beasley, Pagach, \& Warr, 2008; Gordon et al., 2009; Ellul \& Yerramilli, 2013; Hoyt \& Liebenberg, 2011; McShane, Nair, \& Rustambekov, 2011; Pagach \& Warr, 2010) have examined the consequences of RM with regards to organisational performance and value. Other studies (Paape \& Speklé, 2012; Subramaniam et al., 2011) focused on RM effectiveness and organisational outcomes as consequences by applying constructs such as RM design choices, reporting style and RM documentation. Palermo (2014) has demonstrated that RM disclosure influences public sector performance by minimising the costs of borrowing and insurance premiums. Nevertheless, all these studies reported a combination of mixed findings on the consequences of RM. The present study aims to investigate the effect of RM practices on accountability.

\subsection{Risk Management Practices in the Public Sector}

RM studies in the public sector are aimed at enhancing governance, specifically to respond to stakeholders' demand for better control of public resources and to focus on exploring risks existing in government's contractual relationship. The sources of risk could emerge either in information technology outsourcing projects (Ahlan, Arshad, \& Ibrahim, 2012; Khalfan, 2004), government capital project management (Baldry, 1998) including private financing initiatives (PFI) by third parties (Nisar, 2007; Shaoul, Stafford, \& Stapleton, 2012) or other forms of project management (Monetti, Rosa, \& Rocha, 2006). Through a study conducted in Federal Ministries, Azizan and Lai (2013) revealed that RM can enhance performance and corporate governance for the Malaysian public sector. They further suggested that aligning RM initiatives to business objectives and corporate strategy can lead to better decisionmaking and encourage reporting to regulators. The public sector perceives RM as a good governance mechanism which aims to achieve organisational objectives (Woods, 2009). For instance, Guidelines to Enhance Public Sector Governance 2007 and the Prime Minister's Order No. 1, 2009 - Establishment of Committee for Integrity and Governance were issued to promote accountability for the public sector, with emphasis on RM. In the meantime, the Ministry of Science, Technology and Innovation, particularly the Department of Standards, published 
the Risk Management Principles and Guidelines (MS ISO 31000:2010) as a comprehensive guide for the public sector to adhere to the RM principles, framework and process. Given that the objective of the FSBs is to deliver quality services to the public, the similarity of RM practices across the FSBs is expected to comply with the principles and standards of RM as proposed by the ERM integrated framework (COSO, 2004) or the MS ISO 31000:2010.

Notably, stakeholders expect public officials to put controls into place when dealing with risks, for example, strategy, operation, compliance with laws and financial reporting (COSO, 2004). Strategic decisions usually involve uncertain outcomes because they are essential to organisational survival in the long run (Mintzberg, Raisinghani, \& Theoret, 1976). Strategists are aware that corporate disasters can occur if risks are handled improperly, hence they need to know which information is available or not available so that they know how to deal with risk needs (Baird \& Thomas, 1985). Therefore, public sector managers need to equip themselves with the ability to identify and manage risks and opportunities so as to ensure accountability (Queensland Treasury, 2011). Besides being well trained in RM, managers also require the skills to negotiate and manage contracts as well as out-sourced programmes. In fact, literature on RM, whether internationally or locally, has not addressed the issue of RM in the public sector adequately (Baldry, 1998). Therefore, this study aims to contribute to the aspiration of the Malaysian government in enhancing governance by examining the role of RM practices in promoting accountability.

FSBs are the operating arms of the federal government; their role is to implement all programmes that are related to the public sector's reform initiatives. This study selected the FSBs as samples because they are the major consumers of governmental operations and capital grants. The alignment of the FSB's strategic mission with the government's aspirations has led FSBs to pursue new performance measures and more challenging targets. However, unexpected implications on the public sector's reform initiatives could erode the control efforts and impact their accountability (Nyland \& Petterson, 2015). Furthermore, the transformation of the public sector in terms of restructuring and operations through hybrid formations such as public-private collaborations and private financing initiatives, are exposing the public sector to greater risks. This further challenges its control structure and accountability (Nyland \& Petterson, 2015). Therefore, the risk management practices (RM) of the Malaysian FSBs need to be further substantiated. 


\subsection{Performance Measurement System Use}

To derive the dimensions of the PMS used in this study, Henri's (2006b) work which classifies management and accounting information systems was referred. This is because these dimensions have been empirically tested and are relevant to the performance measurement and decisionmaking environment of the public sector. The first of Henri's (2006b) dimension is monitoring which refers to performance measures used for providing feedback of performance and for communication. Monitoring involves tracking the progress towards goals and comparing outcomes to expectations. The PMS is used as a diagnostic control (Simons, 1990) that relates to performance measures and reporting (Atkinson, Waterhouse, \& Wells, 1997). It acts as an answering machine (Burchell, Clubb, Hopwood, Hughes, \& Nahapiet, 1980). For instance, the rationale behind the PMS's role in successful transformation is the use of the balanced scorecard (BSC) measures in monitoring the rate of change during the change process and the monitoring of performance after the completion of change (MacBryde, Paton, Bayliss, \& Grant, 2014). The second dimension is attention-focusing which refers to performance measures used by top managers to send signals across the organisation. Attention-focusing provides common focus of the critical success factors, goal targets (key performance indicators or KPIs) and critical uncertainty sent by the top managers throughout the organisation. The PMS is used as an ammunition machine (Burchell et al., 1980) and for interactive control (Simons, 1990). It is meant to encourage employees to focus on organisational goals (Atkinson et al., 1997; Vandenbosch, 1999). The clarity of the performance measures served highlight areas of poor performance which needs attention (MacBryde et al., 2014).

Several studies (Abdali et al., 2013; Bakar et al., 2011; Bolton, 2003; Cunningham \& Harris, 2005; Kloot, 2009; Saliterer \& Korac, 2013; Tan, 2014) have demonstrated the PMS as an important tool for discharging accountability in the public sector. However, Woods (2008) suggested that further research is needed to observe the relationship between strategic control and risk management. The amount of studies examining the PMS as a driver of RM practices, however, has been few. PMS use in risk management studies states that agreed performance measures help the management team to focus on exactly what they are trying to control (Loosemore et al., 2006). Andrews (2014) also pointed out that performance management has a positive impact on outcomes for service users. Performance management manifests the improvement of the public services' effectiveness. As RM practices 
assure the achievement of objectives, RM success is measured based on the achievement of pre-set key performance indicators or performance measures (Loosemore et al., 2006). In considering the dimensions of the PMS used by Henri (2006b), this study also includes PMS use for monitoring and PMS use for attention-focusing.

Meanwhile, Mohamad and Ismail (2014) mentioned that there is a considerable range for PMS development and operationalisation since its 'usage' has not been well-defined. The existing theoretical link between PMS use and accountability is further developed by investigating the circumstances that would make PMS use predictive of accountability. Two studies were conducted in Malaysia to investigate the mediating effect of RM on the relationship between internal audit and organisational performance (Roslan \& Dahan, 2013a) and the relationship between risk culture and organisational performance (Roslan \& Dahan, 2013b). These studies show that RM mediates the relationships. Although previous studies have shown that organisational control system and its components mediate organisational performance (Chenhall, 2003), there are limited studies investigating the role of the different processes of RM as a mediator.

In line with its quest for public sector reforms, the Government of Malaysia also released Circular 2/2005 (Government of Malaysia, 2005) to present the performance measures (KPI) the government expected of the public sector. A new cabinet position was also created to support this implementation (Mucciarone \& Neilson, 2012). The government aimed to measure the performance of the public sector with a special focus on the National Key Result Areas. Hence, the PMS has become the gist of the public sector reform for promoting accountability. The performance measures or the key performance indicator (KPI) has a significant influence on RM practices. Organisational objectives are usually identified through consultations with stakeholders and they are measured by defining the KPIs associated with each objective. Only after having a clear list of objectives and KPIs are manager allowed to identify the risk and opportunities associated with a decision (Loosemore et al., 2006). Agreed KPIs help the management team to focus their mind on what exactly they are trying to control. Since RM is about achieving objectives, these measurable criteria thus becomes the target against which RM success is measured and judged (Loosemore et al., 2006). The performance measures used for monitoring the progress towards the achievement of goals can send an early signal to the RM department to identify and mitigate all risks that could cause a variance from the 
target (Arena \& Arnaboldi, 2014). Therefore, the present study aims to investigate the role of PMS use as the internal driver of RM practices in the public sector.

\section{Hypotheses Development}

The conceptual model predicts the relationship among the exogenous variables, PMS use for monitoring and PMS use for attention-focusing, the endogenous variable, accountability and the mediating variable and RM practices.

\subsection{Relationship between PMS Use for Monitoring and RM Practices}

The relationship between PMS use and a variety of measures was previously studied by Henri (2006b). He related various measures to the financial and non-financial metric of balanced scorecards and found that a monitoring use of PMS is related to a higher variety of measures. Commonly, organisations use PMS to monitor progress towards strategic goals. RM could then be used to identify the factors that affect the achievement of these goals (Beasley, Chen, Nunez, \& Wright, 2006). Notably, performance measures provide managers with the targeted performance data. These become the input for risk identification activities based on the sources of risk and their potential causes (Arena \& Arnaboldi, 2014). Since RM focuses on the potential events and is intended to identify and manage future unpredictable events that may adversely affect organisations (Mikes \& Kaplan, 2014), PMS use can define targeted goals which need to be protected against risk. The use of the PMS for increasing the monitoring to a higher extent by top management would lead to more frequent executions of risk identification activities. Therefore, PMS use for monitoring will have an effect on RM practices. Based on this, the hypothesis is formulated as:

$\mathrm{H}_{1}$ : There is a positive relationship between PMS use for monitoring and RM practices within the organisation.

\subsection{Relationship between PMS Use for Attention-Focusing and RM Practices}

The use of performance measures for exploratory purpose could enhance performance, depending on the use and clarity of goals and the ability to select performance metrics (Speklé \& Verbeeten, 2014). Henri 
(2006b) found that the attention-focusing use of PMS is linked to a higher variety of measures (financial and non-financial). Managers who use performance measures or KPIs for attention focusing will relate critical success factors with information on the potential causes of deviation from the RM activities at the planning stage itself (Arena \& Arnaboldi, 2014). The critical success factors narrow the result area to be focused for risk identification activities. In addition, the timely identification of the causes of risks help managers to send early signals across the organisation so as to assure a common focus on objectives. The use of PMS for attention-focusing, to a higher extent, would lead to more frequent executions of risk identification activities. Therefore, PMS use for attention-focusing will influence RM practices. Based on this, the hypothesis is formulated as:

$\mathrm{H}_{2}$ : There is a positive relationship between PMS use for attentionfocusing and RM practices within the organisation.

\subsection{Relationship between RM Practices and Accountability}

Accountability is a theoretical cornerstone for understanding how management controls change or hybridise (Nyland \& Petterson, 2015). Different management controls may facilitate different forms of accountability in organisations. Previous studies (Said et al., 2014) had found that mission based management practices act as factors that influenced accountability in non-profit organisations. As RM practices are associated with organisational mission accomplishments, it can thus be classified as mission based management. Halachmi (2003) had recommended that accountability and RM be connected in a RM system design. Furthermore, in meeting the accountability goals of the educational system (no child left behind policy), schools in Texas also used RM techniques to analyse standard test scores data so as to make decisions that would minimise risks for schools such as excluding low scoring students (student at-risk) (Heilig, Young, \& Williams, 2012). Although there was a lack of empirical evidence showing the effect of RM practices on organisational accountability, as a control mechanism, RM has the potential to promote public sector accountability. This argument led to the prediction that RM practices will promote accountability in terms of risk-based control and decision. Thus, the hypothesis is formulated as:

$\mathrm{H}_{3}$ : RM practices are positively related with accountability. 


\subsection{Mediating Effect of RM Practices on Accountability}

The positive relationship between PMS and accountability has been illustrated in many studies (e.g. Arena \& Arnaboldi, 2014; Rasid, Golshan, Ismail, \& Ahmad, 2012; Söderholm \& Norrbin, 2013; Woods, 2008). In fact, PMS is inseparable from RM. There were notions (Heilig et al., 2012; Halachmi, 2003) which suggest the potential relation between RM and public sector accountability. There were even calls to enhance risk disclosure in the UK companies as a measure to help stakeholders to have more knowledge of companies' risk profiles (Linsley \& Lawrence, 2007). Considering the positive relation between PMS on RM practices (Loosemore et al., 2006; Chapman, 2006), it is presumed that systematically practised RM would promote accountability.

The RBV supports this notion, where organisations could employ different strategies to outperform each other and to achieve a competitive advantage, using different resources. To relate this with the present study, the RM system, as a resource of the RBV (based on the information gathered from the PMS), produces FSBs with risk position information as a means to improve accountability. Hence, organisations with RM practices and the growing public sector reputation (resource of RBV) could lead the FSBs to gain more competitive advantages. Therefore, by sustaining these resources, FSBs could attract future investments (Wang et al., 2003).

The organisation's control system and its components have been proven to act as a mediator on organisational performance (Chenhall, 2003). However, literature addressing the mediating role of RM practices has been insufficient except for Roslan and Dahan (2013a; 2013b). Since it is hypothesised that PMS use for various purposes are related to RM practices and that RM practices are related to accountability, it can be hypothesised that RM practices play a mediating role in the relationship between PMS use and accountability. Hence, the hypotheses are formulated as:

$\mathrm{H}_{4}$ : RM practices mediate the relationship between PMS use for monitoring and accountability.

$\mathrm{H}_{5}$ : RM practices mediate the relationship between PMS use for attention-focusing and accountability.

\subsection{Research Framework Development}

The RBV model views scarce internal resources as the key to superior performance that enables the organisation to gain a competitive advan- 
tage (Barney, 1991). The competitive advantage of Malaysian FSBs depends on their internal resources including the PMS information and the RM system and their ability to exploit these resources rather than the external environment (Wernerfelt, 1984). Hence, the first part of the conceptual framework theorised the relationship between PMS use (as a resource of RBV) and RM practices (as a resource of RBV) from the perspective of the resource-based view (RBV). This prediction extends on Henri's (2006a) work which examined MCS use and RBV capabilities. In that regard, this study examines two dimensions of PMS use: monitoring and attention-focusing.

Notably, PMS use and RM practices are key resources to superior performance which leads to better accountability in terms of risk-based decision and control. Therefore, these resources need to be sustained. In addition, future investment can be attracted through reputation earned from an enhanced accountability. Hence, the second part of the conceptual framework theorised the relationship between RM practices and accountability by using the RBV. This prediction extends on Andersen (2008) and Wang et al.'s (2003) work which demonstrated that RM (an RBV resource) could lead to superior performance and a competitive advantage. Based on the MS ISO 31000:2010, this study examines the three main processes of $\mathrm{RM}$ practices including risk identification, risk assessment and risk monitoring. Thus, it can be summarised that FSBs treasure RM as best practice and the tool of accountability. When exploited, these could lead to a competitive advantage for growth sustainability, in terms of better organisational reputation and investment.

According to the foregoing discussions, the following research framework is proposed.

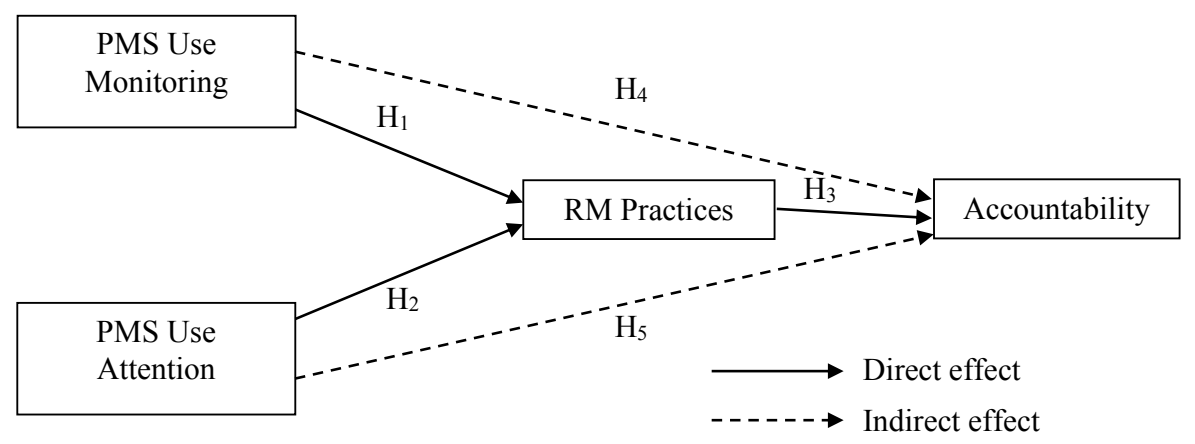

Figure 1: Research Framework 


\section{Methodology}

\subsection{Research Design}

This study aims to investigate the predictive effects of PMS use and RM practices on accountability by using the mediation framework. Since RM practices in the Federal Statutory Bodies (FSBs) of Malaysia are the focus of this study, it is assumed that the FSBs have adopted RM. The population of the study consisted of 112 FSBs across 22 ministries and 400 main branch offices. The Auditor General's Reports for the year 2010 and 2011 were reviewed to obtain findings on RM practices and FSBs which have implemented a comprehensive RM framework. The review revealed that only 217 of them have adopted and practised RM. Therefore, 217 self-administered questionnaires were disseminated to the respondents via their personal emails. As the respondents of this study, these FSBs were noted to have a complete organisation structure with more than 100 employees. This criteria ensures that a formal performance measurement system (Henri, 2006a) and RM are being practised. The respondents were chief executive officers, CROs and chief finance officers. Following this, their personal assistants were contacted to remind them about the survey, to explain the purpose of the survey and to ensure that the survey had been assigned to the person in charge of RM. In some cases, an alternate email address was also obtained from the FSBs to redirect the survey to the right respondents. Since the unit of analysis of this study is the organisation (FSBs), only one respondent from each sample was chosen to represent their organisations. Therefore, the key informants of this study include the CROs, management accountants, strategic planning managers and internal auditors.

Measures for the RM practices and accountability were adapted from Al-Tamimi and Al-Mazrooei (2007) and Geer, Maher and Cole (2008), respectively while measures for the PMS use were adapted from Henri (2006b). The original scales of the questionnaire were revised to suit the need of the present study and to reduce method bias due to same scale format (MacKenzie, Lee, \& Podsakoff, 2003). Several steps were also taken to ensure the instrument's quality and validity. This include the initial development, expert's recommendation, pre-test and pilot test. Initially, indicators of the questionnaire were decided based on an extensive review of the literature on RM, MCS and public sector accountability. Next, the academics' and practitioners' comments were obtained where the academics represent the subject and methodology experts. These academics comprised qualified professors 
who specialised in management accounting practices, RM and research methodology and business statistics.

The questionnaire was later run through a pre-test to ensure suitability for the current research population so that quality data are retrievable for each variable. A pre-test was conducted among twenty respondents from several FSBs, including Universiti Teknologi Malaysia (Johor Bahru) and Bank Rakyat, Taman Universiti (Johor Bahru). The pre-test led to some modifications of the questionnaire items, structure and scale as well as clarity of words. Several original items related to RM practices and credit risk analysis specified for the banking environment, were eliminated to suit the public sector environment. The remaining indicators used to measure RM practices include: (1) risk identification (organisations carries out a systematic risk identification and develops opportunity identification procedures or changes in risk), (2) risk assessment (organisation assesses likelihood of risk, assesses risk using qualitative method, analysis opportunities, analysis cost benefit) and (3) risk monitoring (organisation monitors RM effectiveness, risk control is appropriate and organisation's reporting supports RM). The respondents were asked to indicate their level of agreement on the RM practices in their own organisation. For accountability, the indicators measured the organisation's exercise so as to evaluate service efficiency and to respond to complaints, the organisation determines a clear mission or goal and established conflict of interest policy. The respondents were asked to indicate the organisation's emphasis on accountability. As for the PMS use, the respondents were asked to indicate the extent to which top management used the PMS for monitoring and attention-focusing.

The questionnaire items were then used to run a pilot test among thirty respondents. The participating organisations include Universiti Teknologi Malaysia (6), Bank Rakyat (M) Berhad (6), Kumpulan Wang Persaraan Diperbadankan (6), Lembaga Tabung Haji (2) and Kumpulan Wang Simpanan Pekerja (10). These participants were from FSBs that deliver vast services including banking, finance, retirement funds and education.

The internal consistency test of the constructs extracted from the pilot test revealed that Cronbach's alpha values ranged between 0.841 and 0.968 (Nunnally, 1978). Therefore, all the measures were reliable. The questions were confirmed to be valid for further data collection. There were no major alterations or corrections made to the questionnaire after the pilot test. The Cronbach's alpha value is shown in Table 1. 
Table 1: Cronbach's Alpha Value of Constructs

\begin{tabular}{lc}
\hline Dimensions & Cronbach's Alpha \\
\hline PMS Use for Monitoring & 0.911 \\
PMS Use for Attention-focusing & 0.939 \\
RM Practices & 0.968 \\
Accountability & 0.841 \\
\hline
\end{tabular}

Data collection lasted for a period of three months where 130 organisations responded to the survey, indicating a response rate of 60 per cent. However, the final usable sample was only 110. According to Israel (1992), for a population of 500 at 10 per cent precision level, the sample size required is 83 . Therefore, the remaining samples of 110 were sufficient to represent the population (Israel, 1992). Table 2 represents the demographic information of the respondents.

Table 2: Respondent's Demographic Information

\begin{tabular}{lcc}
\hline Demographic & Frequency $(\mathrm{n}=110)$ & Percentage (\%) \\
\hline Duration of Establishment & 25 & 23 \\
Less than 10 years & 53 & 48 \\
Between 11-49 years & 32 & 29 \\
$>50$ years & & \\
Government Grant & 63 & 57 \\
Receive grant & 47 & 43 \\
Do not receive grant & & \\
Stage of RM Adoption & 50 & 45 \\
Complete RM framework in place & 60 & 55 \\
Partial RM framework in place & & \\
Designation of Respondents & 2 & 2 \\
Chief Executive Officer & 4 & 4 \\
Chief Risk Officer & 24 & 21 \\
Chief Finance Officer/Accountant & 9 & 8 \\
Finance Manager & 2 & 2 \\
Strategic Manager & 14 & 13 \\
Internal Auditor & 55 & 50 \\
Senior Manager & & \\
\hline
\end{tabular}




\section{Results and Discussion}

\subsection{Descriptive Statistics of Constructs}

Table 3 depicts the mean score and standard deviation by items for all constructs including PMS use, RM practices and accountability constructs. The mean for the items of the constructs ranged from a lower bound of 3.68 to an upper bound of 4.30, whereas their standard deviation ranged between 0.638 and 0.967 .

In the survey, managers were requested to indicate the usage of PMS information in the FSBs for each of its dimension. The overall mean of 4.24 for PMS use monitoring, explains that PMS information was

Table 3: Descriptive Statistics of Constructs

\begin{tabular}{|c|c|c|c|c|}
\hline Constructs & Items & Mean & $\begin{array}{l}\text { Standard } \\
\text { Deviation }\end{array}$ & $\begin{array}{c}\text { Overall } \\
\text { Mean }\end{array}$ \\
\hline \multirow[t]{4}{*}{ PMS Use Monitoring } & Track progress & 4.25 & 0.638 & \multirow{4}{*}{4.24} \\
\hline & Review KPI & 4.25 & 0.670 & \\
\hline & Compare outcomes & 4.18 & 0.666 & \\
\hline & Monitor results & 4.30 & 0.643 & \\
\hline \multirow[t]{4}{*}{ PMS Use Attention } & Focus common issues & 3.99 & 0.684 & \multirow{4}{*}{4.06} \\
\hline & Focus CSF & 4.14 & 0.673 & \\
\hline & Enable discussion & 4.06 & 0.770 & \\
\hline & Debate action plan & 4.05 & 0.740 & \\
\hline \multirow[t]{3}{*}{ Risk Identification } & $\begin{array}{l}\text { Carries out systematic } \\
\text { risk identification }\end{array}$ & 3.94 & 0.838 & \multirow{3}{*}{3.91} \\
\hline & $\begin{array}{l}\text { Changes in risk } \\
\text { recognised }\end{array}$ & 3.95 & 0.776 & \\
\hline & $\begin{array}{l}\text { Develop risk identifi- } \\
\text { cation procedure }\end{array}$ & 3.85 & 0.811 & \\
\hline \multirow[t]{4}{*}{ Risk Assessment } & Assesses risk likelihood & 3.96 & 0.765 & \multirow{4}{*}{3.98} \\
\hline & $\begin{array}{l}\text { Assesses using } \\
\text { qualitative method }\end{array}$ & 4.05 & 0.850 & \\
\hline & Analyse opportunities & 3.97 & 0.760 & \\
\hline & Analyse cost benefit & 3.95 & 0.776 & \\
\hline \multirow[t]{4}{*}{ Accountability } & $\begin{array}{l}\text { Evaluate efficiency } \\
\text { frequently }\end{array}$ & 4.07 & 0.738 & \multirow{4}{*}{4.10} \\
\hline & Respond to complaints & 4.25 & 0.732 & \\
\hline & Clear mission/goals & 4.15 & 0.788 & \\
\hline & Conflict of interest policy & 3.91 & 0.811 & \\
\hline
\end{tabular}


used for monitoring to the greatest extent, particularly for monitoring the results (mean 4.30), tracking progress towards goals (mean 4.25) and reviewing KPI (mean 4.25). The overall mean of above 4.00 for the dimension of PMS use attention indicates that PMS information has been used extensively in the FSBs. The moderate use of PMS information was recorded for focusing on a common issue (mean 3.99). Thus, it can be assumed that the high usage of PMS for various purposes might encourage RM practices within the FSBs.

Respondents indicated their agreement on RM practices which include detailed activities involved in the process of risk identification, assessment and monitoring. The overall mean indicated that RM was moderately practised in the FSBs, with higher emphasis on risk assessment (mean 3.98) and risk identification (mean 3.91), followed by risk monitoring (mean 3.81). In the risk identification phase, top management rated that changes in risks were recognised, with organisation's roles and responsibilities (mean 3.95) rated as highly performed activities. Developed procedures for systematic identification of risk and opportunities were least performed as an activity (mean 3.85). In the risk assessment phase, top management strongly agreed on the use of qualitative method to assess the identified risks (mean 4.05) in FSBs. The least emphasis was given to the analysing of cost benefits (mean 3.95). In the risk monitoring phase, top management gave the highest score for the organisation's reporting processes which support the effective management of risks (mean 3.88). The lowest score was given for monitoring the effectiveness of RM as an integral part of the routine management reporting (mean 3.68). Therefore, these results support the assumption that RM is being practised moderately in FSBs although it is a sophisticated and expensive control system, which is more likely to be employed by commercial sectors which are profit oriented.

Respondents were requested to indicate their perception on organisational accountability. Compared to the overall mean value of 4.10 , two items were noted to be above the average mean value and they were highly emphasised in the FSBs. These encompass responses to service related complaints (mean 4.25) and clear mission and goal (mean 4.15). It was noted that the least emphasis was on establishing a written conflict-of-interest policy for the board of directors (BOD) and staff (mean 3.91). Therefore, organisational accountability is an important feature in the public sector which is often sought by stakeholders for investments and are given high emphasis. 


\subsection{Measurement Model Assessment}

The final usable samples included for analysis comprise 110 respondents which is adequate to run the PLS-SEM (Cohen, 1992). The reflective measurement model was chosen to model the relationship between measures and first-order latent construct, after fulfilling the specified criteria (Jarvis, MacKenzie, \& Podsakoff, 2003; Hair, Hult, Ringle, \& Sarstedt, 2014). The constructs used for this study was tested for convergent validity, based on the factor loadings, composite reliability (CR) and average variance extracted (AVE) (Hair et al., 2014). Table 4 presents the composite reliability for PMS use monitoring (0.941), PMS use attention (0.876), risk management practices (0.938) and accountability (0.890). The recorded CR values of between $0.8-0.9$ indicated that there was an internal consistency among the items and the constructs they represented. As a result, the items used in the study were deemed reliable measures. The factor loadings for all items ranged between 0.792 and 0.939 , exceeding the threshold value of 0.708 (Hair et al., 2014). Hence, the indicator reliability of all items were at satisfactory level. The assessment of the average variance extracted (AVE) for each construct exhibited the AVE value of more than the threshold value of 0.5 . Therefore, the measurement model of this study has established an adequate convergent validity and all items of the three constructs were valid measures.

The discriminant validity of the measurement model was assessed based on two techniques: (1) Fornell-Larcker criterion and (2) cross loadings. Table 5 exhibits the results of the computed square roots of the $\mathrm{AVE}$ and off-diagonal values which exhibited the inter-correlation value between constructs. The results indicated that the square roots of the AVE (bold) of all constructs exceeded their correlations with other constructs (off-diagonal values), thus, the Fornell-Larcker criterion was fulfilled. Simultaneously, the cross loading results indicated that all measurement indicators loaded higher on their own construct when compared to other constructs. Based on the results of both techniques, the measurement model has established its discriminant validity. To summarise, the outer measurement model is reliable and valid, thus the measurement model can be used to estimate the parameters in the inner structural model.

\subsection{Structural Model}

The structural model evaluation validates the collinearity among constructs, the coefficient of determination $\left(\mathrm{R}^{2}\right)$, effect sizes $\left(\mathrm{f}^{2}\right)$, predictive 
Risk Management Practices to Strengthen Public Sector Accountability

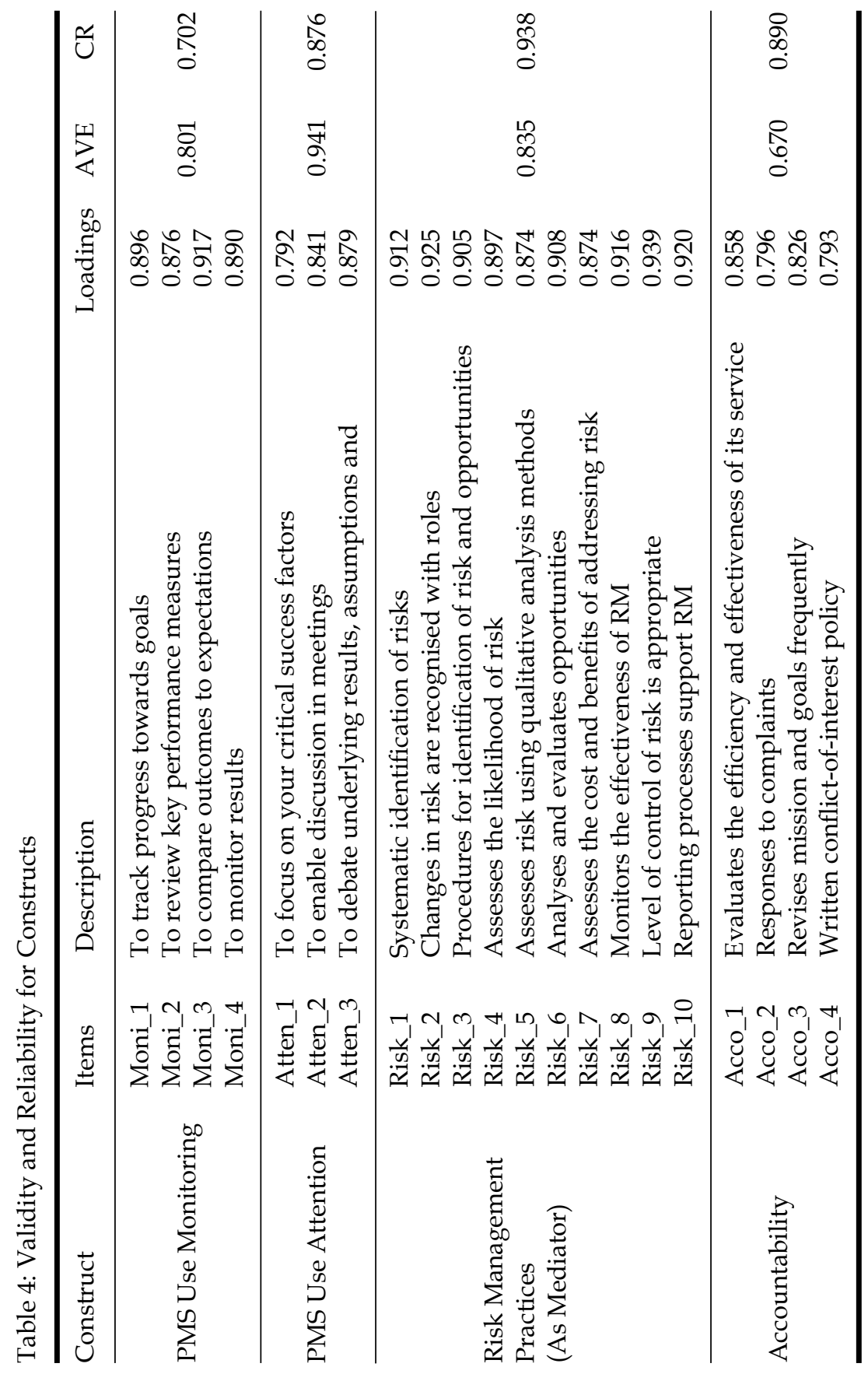


Table 5: Inter-correlation Matrix (Fornell-Larker Criterion)

\begin{tabular}{lcccr}
\hline & Accountancy & $\begin{array}{c}\text { PMS Use } \\
\text { Attention }\end{array}$ & $\begin{array}{c}\text { PMS Use } \\
\text { Monitoring }\end{array}$ & $\begin{array}{c}\text { RM } \\
\text { Practices }\end{array}$ \\
\hline Accountability & $\mathbf{0 . 8 1 8}$ & & & \\
PMS Use Attention & 0.544 & $\mathbf{0 . 8 3 8}$ & & \\
PMS Use Monitoring & 0.580 & 0.673 & $\mathbf{0 . 8 9 5}$ & $\mathbf{0 . 9 1 4}$ \\
RM Practices & 0.663 & 0.536 & 0.571 & $\mathbf{0 . 5 1 4}$ \\
\hline
\end{tabular}

Note: Values in the diagonal (bold) represent the square root of the AVE and the offdiagonal values exhibit the correlations.

relevance $\left(Q^{2}\right)$ and path coefficient $(\beta)$ (Hair et al., 2014). First, the collinearity among the predictor constructs was tested. Results showed that collinearity was not an issue as the variance inflation factor (VIF) was below 5 . Hence, the structural model was fit for further evaluation. Second, the coefficient of determination $\left(\mathrm{R}^{2}\right.$ value) was assessed. Figure 2 indicates that the $R^{2}$ value for $R M$ practices is 0.385 and the $R^{2}$ value for accountability is 0.446 , both were significant at the 0.01 probability level. The $\mathrm{R}^{2}$ value indicates that PMS use monitoring, PMS use attention and RM practices explained 44 per cent of the variance in accountability (endogenous variable), whereas 38 per cent variance in RM practices

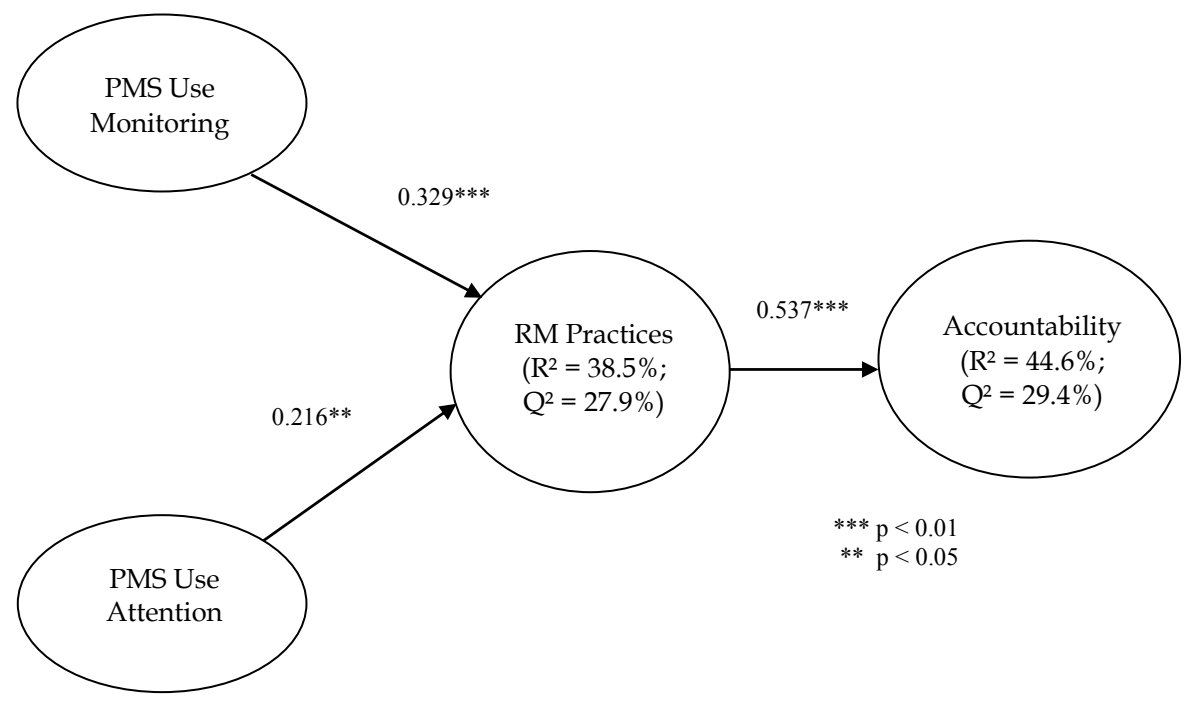

Figure 2: Structural Model 
was explained by PMS use monitoring and PMS use attention. Based on Cohen (1988), the $R^{2}$ value for the endogenous latent variables above 0.26 is considered large. Conversely, the use of $\mathrm{R}^{2}$ value for understanding the model's predictive accuracy will result in an inherent bias. This is due to the fact that even a non-significant exogenous construct will increase the $R^{2}$ value. Therefore, the $R^{2}$ adjusted value needs to be considered when comparing models (Hair et al., 2014). The $\mathrm{R}^{2}$ adjusted value recorded for RM practices was 0.368 and for accountability, it was 0.430 , both of which were still considered large (Cohen, 1988).

Further, in the exogenous constructs, RM practices have $\mathrm{f}^{2}$ effect sizes of 0.132 , for explaining accountability (Table 6). On the other hand, the exogenous constructs, PMS use monitoring and PMS use attention, have $\mathrm{f}^{2}$ effect sizes of 0.087 and 0.037 , respectively. This signifies that PMS use monitoring is more important than PMS use attention for explaining the variance in RM practices. Overall, the exogenous constructs have small effect sizes in explaining the endogenous variables (Cohen, 1988).

Third, the cross validated redundancy results as in Figure 2 indicates that the $\mathrm{Q}^{2}$ value for both accountability $(0.279)$ and RM practices (0.294) were more than zero. This indicates that the model has predictive relevance.

Fourth, after assessing the $\mathrm{R}^{2}$ values and the $\mathrm{Q}^{2}$ values, the path coefficient was evaluated to further validate the structural model and the proposed hypotheses. According to Hair, Ringle and Sarstedt (2011), the path coefficient value which gives impact to the structural model must be at least 0.1 . Table 7 shows the results of the structural model estimation detailing the path coefficients, standard error and t-statistics, for all hypothesised paths. It is noted that path coefficient value $(\beta)$ ranges from 0.216 to 0.537 , with positive signs and are significant.

Table 6: Summary of Results

\begin{tabular}{lcclccc}
\hline & \multicolumn{2}{c}{ Accountability } & & \multicolumn{2}{c}{ RM Practices } \\
\cline { 2 - 3 } \cline { 6 - 7 } & $\begin{array}{c}\text { Path } \\
\text { coefficient }\end{array}$ & $\begin{array}{c}\mathrm{f}^{2} \\
\text { effect size }\end{array}$ & & $\begin{array}{c}\text { Path } \\
\text { coefficient }\end{array}$ & $\begin{array}{c}\mathrm{f}^{2} \\
\text { effect size }\end{array}$ \\
\hline RM Practices & 0.537 & 0.132 & & - & - \\
PMS Use Monitoring & - & - & & 0.329 & 0.087 \\
PMS Use Attention & - & - & & 0.216 & 0.037 \\
\hline
\end{tabular}


Table 7: Structural Estimates for Hypotheses Testing

\begin{tabular}{lccc}
\hline Paths & $\begin{array}{c}\text { Path } \\
\text { Coefficient } \beta\end{array}$ & $\begin{array}{c}\text { Standard } \\
\text { Error }\end{array}$ & t-statistics \\
\hline PMS Use Monitoring $\rightarrow$ RM Practices & 0.329 & 0.103 & $3.194^{* * *}$ \\
PMS Use Attention $\rightarrow$ RM Practices & 0.216 & 0.099 & $2.172^{* *}$ \\
RM Practices $\rightarrow$ Accountability & 0.537 & 0.142 & $3.787^{* * *}$ \\
\hline
\end{tabular}

Note: Critical t-values: **2.57 (probability $<0.01$ ); **1.96 (probability <0.05).

Based on the analysis, RM practices were affected directly by PMS use monitoring $(\beta=0.329, \mathrm{t}=3.194, \mathrm{p}<0.01)$. Thus, $\mathrm{H}_{1}$ is supported. RM practices were also affected directly by PMS use attention $(\beta=$ $0.216, \mathrm{t}=2.172, \mathrm{p}<0.05)$. Hence, $\mathrm{H}_{2}$ is supported. On the other hand, accountability is affected directly by RM practices $(\beta=0.537, \mathrm{t}=3.787$, $\mathrm{p}<0.01$ ). This suggests that RM practices were positively related to accountability and were statistically significant. As a result, $\mathrm{H}_{3}$ is also supported.

Fifth, the structural model was examined for mediating effect. This study had proposed the mediating effect of RM practices on accountability through hypotheses $\mathrm{H}_{4}$ and $\mathrm{H}_{5}$. Since PMS use for monitoring and PMS use for attention-focusing were directly related to RM practices and at the same time, RM practices were directly related to accountability, the mediating effect of RM practices can be assessed (Preacher \& Hayes 2008). Therefore, the bootstrapped for indirect effect was computed. This approach exhibited a higher level of statistical power when compared with the Sobel Test (Preacher \& Hayes, 2008). The bootstrapping results, as shown in Table 8 , revealed that there was a positive indirect effect of PMS use monitoring on accountability $(\beta=$ $0.177, \mathrm{t}=2.223, \mathrm{p}<0.05)$. There was also a positive indirect effect of PMS

Table 8: Indirect Effect

\begin{tabular}{lccc}
\hline Paths & $\begin{array}{c}\text { Path } \\
\text { Coefficient } \\
\beta\end{array}$ & $\begin{array}{c}\text { Confidence } \\
\text { Interval } \\
\text { Lower }\end{array}$ & $\begin{array}{c}\text { Confidence } \\
\text { Interval } \\
\text { Upper }\end{array}$ \\
\hline PMS Use Monitoring $\rightarrow$ Accountability & 0.177 & 0.038 & 0.347 \\
PMS Use Attention $\rightarrow$ Accountability & 0.116 & 0.016 & 0.239 \\
\hline
\end{tabular}

Note: RM as mediating variable. 
use attention-focusing on accountability $(\beta=0.116, \mathrm{t}=2.055, \mathrm{p}<0.05)$. Therefore, hypotheses $\mathrm{H}_{4}$ and $\mathrm{H}_{5}$ are supported. Simultaneously, the 95 per cent bootstrapped confidence interval level for the indirect effect of PMS use monitoring and PMS use attention on accountability, did not straddle a zero between the upper and lower level limit. This confirms that RM practices mediate the relation between PMS use monitoring and accountability as well as between PMS use attention-focusing and accountability.

This study had attempted to investigate the predictive effects of the different dimensions of the performance measurement system (PMS) use and risk management (RM) practices on accountability through mediators. The results of the test signified a positive relationship between PMS use for monitoring and RM practices. This finding suggests that the use of PMS for monitoring at a greater extent in the FSBs would trigger more RM activities. PMS use for monitoring in the FSBs involves monitoring results, tracking progress toward goals, reviewing KPIs and comparing outcomes to expectations. Thus, the PMS provide accurate strategic information and key result areas which need to be focused in achieving organisational objectives. However, potential risk and uncertainties in the environment could hinder the achievement of such objectives. Therefore, the use of PMS for monitoring the achievement of organisational strategic objectives could trigger risk identification for determing risks and their causes (COSO, 2004). This could hinder the achievement of goals.

The findings of this study are consistent with the outcome of Henri (2006b) who argued that monitoring use of PMS is a conventional type of control system which represents the basic management activities performed in an organisation. The finding of this study also supports RBV, which considers the PMS information as a resource (Hooley, Broderick, \& Moller, 1998) which can be used to monitor the achievement of organisational objectives and for sending signals of key success factors across the organisation. This key resource to superior performance could lead to better accountability of the public sector because disclosing performance information including the organisation's efficiency, effectiveness and other non-financial information to the stakeholders would enhance public trust and organisational reputation (resource). Subsequently, this attracts future investments. Therefore, information produced from the PMS are key resources for superior performance that needs to be sustained in order to gain a competitive advantage (Barney, 1991). 
Another remarkable finding of this study suggests that the use of the PMS for attention-focusing in the FSBs influences systematic risk identification. PMS use for attention-focusing in the FSBs involved focusing on critical success factors and sending signals on critical success factors and goal targets across the same organisation. However, the critical success factors may fail due to unrecognised potential risks and uncertainty. Eventually, the source of identified risks need to be assessed so as to decide on the risks treatment plan. Furthermore, organisations' objectives are measured by defining KPIs or performance measures associated with each objective. KPIs allow managers to identify risks and opportunities associated with a decision (Loosemore et al., 2006). In addition, PMS use for attention-focusing points out the nature of the RM programmes, the areas to identify sources of risk and to provide accurate information to be communicated across the organisation. Therefore, it can be concluded that Malaysian FSBs that use PMS for attention-focusing, were more likely to identify risks associated with its critical success factors and goals. It is also suggested that the FSBs continue to improve their communication networks so as to foster the PMS information flow and to ensure that information is being transmitted across organisations as a means of ensuring a common focus on objectives and benefits are identified from the risk identification phase.

The significant results of this study emphasises the positive relationship between RM practices and accountability. This finding suggests that systematic risk identification is important for promoting accountability among FSBs in Malaysia. Although not all FSBs have developed the necessary procedure for risk identification, they have all been systematically identifying risks. A comprehensive list of risks derived by managers from different departments have provided the risk information for stakeholders to make better decision making. Unlike traditional accountability which has focused primarily on financial data and on the legitimacy of spending (Schillemans, Van Twist, \& Vanhommerig, 2013), the FSBs transformation drive the demand for a risk management system to improve its decision-making and accountability. Therefore, it can be concluded that risk identification leads to better accountability of the Malaysian FSBs.

The finding of this study is consistent with Hayne and Free (2014) who posited that RM reduces uncertainty, insecurity, ambiguity and imperfection, thereby enhancing the image of innovation (reputation) in organisations. These outcomes of RM practices promote better accountability. The current finding also supports Halachmi's (2003) 
recommendation to connect accountability and risk management in the risk management system so that public sector governance can be fortified (Greiling \& Halachmi, 2013). An effectively implemented RM can improve organisational performance (Beasley et al., 2006). Specifically, it develops more interactive techniques of event identification that lead to better organisational performance (Mikes \& Kaplan, 2014).

Drawing from the perspective of the RBV, it can be deduced that RM capability is a key resource that could improve the performance, decision-making and control of the public sector towards enhancing its accountability. Besides RM practices, the spillover effect of reputation emerging from effective RM practices is also considered a RBV resource (Hooley et al., 1998) that could lead to a competitive advantage for the FSBs, in terms of firm-specific investments (Wang et al., 2003). Therefore, these resources need to be sustained. The current study supports the RBV which posits that through investment in resources such as the RM system which is organised to align with the achievement of organisational objectives, superior performance in terms of accountability can be achieved. Systematic risk identification enhances the reputation of the public sector among stakeholders (Andersen, 2008). This, in turn, produces a competitive advantage for the public sector through future fundings, deposits, investments and contracts.

This study found that Malaysian FSBs which use PMS information for various purposes place a greater emphasis on RM practices to enhance accountability. The results generated were consistent with the resource-based view which posits the need to sustain valuable resources (PMS information, RM system and reputation) for a competitive advantage. In Malaysian FSBs, the greater use of PMS for monitoring and attention-focusing could improve accountability by implementing RM. The result of this study contributes to the existing theory by emphasising on the effects of RM practices on accountability. This can be accomplished with the influence of the right drivers.

The empirical result also supports the significant role of RM practices as a mediator in the relationship between PMS use for monitoring, PMS use for attention-focusing and accountability. Both PMS use (monitoring and attention-focusing) predict accountability directly and indirectly through RM practices but the PMS use for monitoring has a stronger effect on accountability. This result, therefore implies that the role of RM practices in promoting accountability in FSBs is crucial. FSBs with increased use of PMS for monitoring would demand more RM practices so as to have a complete picture of the 
organisation's risk profile as a means of achieving its targeted goals. Therefore, RM practices with high levels of PMS use for monitoring could help FSBs to enhance accountability. This finding is consistent with previous studies which also found the mediating effect of RM on organisational performance (Roslan \& Dahan, 2013a; 2013b) in Malaysian companies.

\section{Conclusion}

This study suggests that organisational accountability can be improved by practising RM which is driven by PMS uses, as an ultimate aim to achieve organisational objectives. There are several contributions derived from this study. First, this study suggests that RM practices can contribute in improving public sector accountability (new consequence) by investigating the relationship between RM practices and accountability. Second, this study contributes to the body of knowledge by suggesting that among the new drivers that affect the different processes of RM, the construct of PMS use for monitoring and PMS use for attention-focusing should be included. Third, this study focusses on the indirect effect of the RM practices on accountability. The findings of this study suggest that with the appropriate use of the PMS, the practices of RM can contribute to better public sector accountability. This study incorporates variables taken from previous studies such as management control system (i.e. PMS), accountability and risk management. Although there are numerous contingencies or other theoretical framework of RM, to date, there has been no framework for studying the mediating effect of RM practices using RBV with different drivers of RM practices and accountability as the consequence. Therefore, this study contributes significantly to the literature on the mediating role of RM practices.

Despite the useful insights gained in the relationship between PMS use, RM practices and accountability, there are also some limitations that should be considered. First, the quantitative research limits the research inquiry process due to some degree of its inadequacy to gain an understanding of the respondents' feelings, impressions and viewpoints. Therefore, critical realism should be the focus of attention in future RM research. Future research should take the viewpoint that risk management is complex and may require multiple investigations in understanding its realities. Second, this study used a cross-sectional design where data were collected from the FSBs and their branch 
offices, at a single point in time. A key weakness of cross-sectional studies is that it does not allow one to draw firm conclusions regarding the causal direction of the relationships between the exogenous and endogenous variables. Given the limitation of the data for causality testing, future research should examine the causal processes underlying the relationship between PMS use, RM practices and accountability. Future research should also consider a longitudinal research design to examine the continuity of the responses and to track changes over time. This study can be extended by examining other moderators such as organisational culture and performance measure properties within the same relationship. A field based study on this topic would also provide an in-depth perspective into the variations in RM practices for organisations and the impact of RM practices on accountability.

This study provides employers of the public sector with new ways to improve accountability in their organisation. In particular, this study offers some practical implications to the literature by providing guidance for professionals, decision makers, managers, CROs and auditors on the appropriate RM processes for different uses of the PMS. The findings revealed that PMS use for monitoring and attention-focusing was more related to risk identification. This study further suggests that more sophisticated risk assessment method is demanded in the public sector to cater to strategic decision making based on pre-set performance measures or KPIs. FSBs should invest more on risk identification activities to identify all their potential risks and opportunities that are related to the FSBs' objectives since this process can promote accountability. As a matter of act, the findings of this study could provide guidance to the Auditor General of Malaysia to improve the existing indicators of the Financial Management Accountability Index which are used for ranking FSBs in terms of their financial management and control.

\section{References}

Abdali, S., Hourani, M.A., Abuerrub, A, \& Shambour, Q. (2013). Toward a conceptual framework for integrating enterprises performance and risk management. Journal of Management Research, 5(4), 145-166. http://dx.doi. org/10.5296/jmr.v5i4.4395

Ahlan, A.R., Arshad, Y., \& Ibrahim, S.N.S. (2012, April). An empirical study on the risk management strategies of IT outsourcing in Malaysia public sector. Paper presented at the International Conference on Information Management and Evaluation, Ankara, Turkey. 
Almqvist, R., Grossi, G., van Helden, G.J., \& Reichard, C. (2013). Public sector governance and accountability. Critical Perspectives on Accounting, 24(7-8), 479-487. http://dx.doi.org/10.1016/j.cpa.2012.11.005

Al-Tamimi, H.A.H., \& Al-Mazrooei, F.M. (2007). Banks' risk management: A comparison study of UAE national and foreign banks. The Journal of Risk Finance, 8(4), 394-409. http://dx.doi.org/10.1108/15265940710777333

Andersen, T.J. (2008). The performance relationship of effective risk management: Exploring the firm-specific investment rationale. Long Range Planning, 41(2), 155-176. http://dx.doi.org/10.1016/j.lrp.2008.01.002

Andersen, T.J. (2009). Effective risk management outcomes: Exploring effects of innovation and capital structure. Journal of Strategy and Management, 2(4), 352-379. http://dx.doi.org/10.1108/17554250911003845

Andrews, R. (2014). Performance management and public service improvement: Evidence review prepared for the Commission on Public Service Governance and Delivery (The Public Policy Institute for Wales (PPIW), Report No. 3). Cardiff, Wales: PPIW.

Arena, M., \& Arnaboldi, M. (2014). Risk and performance management: Are they easy partners? Management Research Review, 37(2), 152-166. http:// dx.doi.org/10.1108/MRR-08-2012-0180

Arena, M., Arnaboldi, M., \& Azzone, G. (2010). The organizational dynamics of enterprise risk management. Accounting, Organizations and Society, 35(7), 659-675. http://dx.doi.org/10.1016/j.aos.2010.07.003

Atkinson, A.A., Waterhouse, J.H., \& Wells, R.B. (1997). A stakeholder approach to strategic performance measurement. MIT Sloan Management Review, 38(3), 25-37.

Azizan, N.A., \& Lai, F-W. (2013). Depth penetration of enterprise risk management model in Malaysian government sector. Journal for Global Business Advancement, 6(2), 138-151. http://dx.doi.org/10.1504/JGBA.2013.053567

Baird, I.S., \& Thomas, H. (1985). Toward a contingency model of strategic risk taking. The Academy of Management Review, 10(2), 230-243. http://dx.doi. org/10.5465/amr.1985.4278108

Bakar, N.B.A., \& Saleh, Z. (2015). Review of literature on factors influencing public sector disclosure: The way forward. Asian Journal of Business and Accounting, 8(2), 155-184.

Bakar, N.B.A., Saleh, Z., \& Mohamad, M.H.S. (2011). Enhancing Malaysian public sector transparency and accountability: Lessons and issues. European Journal of Economics, Finance and Administrative Sciences, 31(April), 133-145.

Baldry, D. (1998). The evaluation of risk management in public sector capital projects. International Journal of Project Management, 16(1), 35-41. http:// dx.doi.org/10.1016/S0263-7863(97)00015-X

Barney, J. (1991). Firm resources and sustained competitive advantage. Journal of Management, 17(1), 99-120. http://dx.doi.org/10.1177/014920639101700108

Baxter, R., Bedard, J.C., Hoitash, R., \& Yezegel, A. (2013). Enterprise risk management program quality: Determinants, value relevance, and the financial 
crisis. Contemporary Accounting Research, 30(4), 1264-1295. http://dx.doi. org/10.1111/j.1911-3846.2012.01194.x

Beasley, M., Chen, A., Nunez, K., \& Wright, L. (2006). Working hand in hand: Balanced scorecards and enterprise risk management. Strategic Finance, 87(9), 49-55.

Beasley, M., Pagach, D., \& Warr, R. (2008). Information conveyed in hiring announcements of senior executives overseeing enterprise-wide risk management processes. Journal of Accounting, Auditing \& Finance, 23(3), 311-332. http://dx.doi.org/10.1177/0148558X0802300303

Beasley, M.S., Clune, R., \& Hermanson, D.R. (2005). Enterprise risk management: An empirical analysis of factors associated with the extent of implementation. Journal of Accounting and Public Policy, 24(6), 521-531. http://dx.doi.org/10.1016/j.jaccpubpol.2005.10.001

Bolton, M. (2003). Public sector performance measurement: Delivering greater accountability. Work Study, 52(1), 20-24. http://dx.doi.org/10.1108/ 00438020310458697

Brennan, N.M., \& Solomon, J. (2008). Corporate governance, accountability and mechanisms of accountability: An overview. Accounting, Auditing \& Accountability Journal, 21(7), 885-906. http://dx.doi.org/10.1108/ 09513570810907401

Broadbent, J., Dietrich, M., \& Laughlin, R. (1996). The development of principalagent, contracting and accountability relationships in the public sector: Conceptual and cultural problems. Critical Perspectives on Accounting, 7(3), 259-284. http:// dx.doi.org/10.1006/cpac.1996.0033

Burchell, S., Clubb, C., Hopwood, A., Hughes, J., \& Nahapiet, J. (1980). The roles of accounting in organizations and society. Accounting, Organizations and Society, 5(1), 5-27. http://dx.doi.org/10.1016/0361-3682(80)90017-3

Burtonshaw-Gunn, S.A. (2017). Risk and financial management in construction. London: Routledge. http://dx.doi.org/10.4324/9781315244112

Chapman, R.J. (2006). Simple tools and techniques for enterprise risk management. Chichester, West Sussex: John Wiley \& Sons, Ltd.

Chenhall, R.H. (2003). Management control systems design within its organizational context: Findings from contingency-based research and directions for the future. Accounting, Organizations and Society, 28(2-3), 127168. http://dx.doi.org/10.1016/S0361-3682(01)00027-7

Cohen, J. (1988). Statistical power analysis for the behavioral sciences. Hillsdale, New Jersey: Lawrence Erlbaum Associates.

Cohen, J. (1992). A power primer. Psychological Bulletin, 112(1), 155-159.

Collier, P.M. (2009). Fundamentals of risk management for accountants and managers: Tools and techniques. Amsterdam: Taylor \& Francis.

Collier, P.M., Berry, A.J., \& Burke, G.T. (2006). Risk and management accounting: Best practice guidelines for enterprise-wide internal control procedures. US: Elsevier. 
Collier, P.M., \& Woods, M. (2011). A comparison of the local authority adoption of risk management in England and Australia. Australian Accounting Review, 21(2), 111-123. http:/ / dx.doi.org/10.1111/j.1835-2561.2011.00126.x

Colquitt, L.L., Hoyt, R.E., \& Lee, R.B. (1999). Integrated risk management and the role of the risk manager. Risk Management and Insurance Review, 2(3), 4361. http://dx.doi.org/10.1111/j.1540-6296.1999.tb00003.x

Committee of Sponsoring Organizations of the Treadway Commission (COSO). (2004). Enterprise risk management - integrated framework. New York: Author.

Cunningham, G.M., \& Harris, J.E. (2005). Toward a theory of performance reporting to achieve public sector accountability: A field study. Public Budgeting \& Finance, 25(2), 15-42. http://dx.doi.org/10.1111/j.0275-1100. 2005.00359.x

Daud, W.N.W., \& Yazid, A.S. (2009). A conceptual framework for the adoption of enterprise risk management in government-linked companies. International Review of Business Research Papers, 5(5), 229-238.

Daud, W.N.W., Yazid, A.S., \& Hussin, H.M.R. (2010). The effect of chief risk officer (CRO) on enterprise risk management (ERM) practices: Evidence from Malaysia. International Business \& Economics Research Journal, 9(11), 5564. http://dx.doi.org/10.19030/iber.v9i11.30

Drew, S.A., Kelley, P.C., \& Kendrick, T. (2006). CLASS: Five elements of corporate governance to manage strategic risk. Business Horizons, 49(2), 127-138. http:/ / dx.doi.org/10.1016/j.bushor.2005.07.001

Dubnick, M. (2005). Accountability and the promise of performance: In search of the mechanisms. Public Performance E Management Review, 28(3), 376-417.

Ellul, A., \& Yerramilli, V. (2013). Stronger risk controls, lower risk: Evidence from US bank holding companies. The Journal of Finance, 68(5), 1757-1803. http://dx.doi.org/10.1111/jofi.12057

Fornell, C., \& Larcker, D.F. (1981). Evaluating structural equation models with unobservable variables and measurement error. Journal of Marketing Research, 18(1), 39-50. http:/ / dx.doi.org/10.1177/002224378101800104

Geer, B.W., Maher, J.K., \& Cole, M.T. (2008). Managing nonprofit organizations: The importance of transformational leadership and commitment to operating standards for nonprofit accountability. Public Performance $\mathcal{E}$ Management Review, 32(1), 51-75.

Golshan, N.M., \& Rasid, S.Z.A. (2012). Determinants of enterprise risk management adoption: An empirical analysis of Malaysian public listed firms. World Academy of Science, Engineering and Technology, 62, 453-460.

Gordon, L.A., Loeb, M.P., \& Tseng, C.Y. (2009). Enterprise risk management and firm performance: A contingency perspective. Journal of Accounting and Public Policy, 28(4), 301-327. http://dx.doi.org/10.1016/j.jaccpubpol. 2009.06.006

Government of Malaysia. (2005). Development administration circular - Guidelines of establishing key performance indicators (KPIs) and implementing performance assessment at the government agency. Putrajaya: Author. 
Gray, A., \& Jenkins, B. (1993). Codes of accountability in the new public sector. Accounting, Auditing \& Accountability Journal, 6(3), 52-67. http://dx.doi. org/10.1108/09513579310042560

Greiling, D., \& Halachmi, A. (2013). Accountability and organizational learning in the public sector. Public Performance E Management Review, 36(3), 380-406.

Hair, J.F., Hult, G.T.M., Ringle, C.M., \& Sarstedt, M. (2014). A primer on partial least squares structural equation modeling (PLS-SEM). Thousand Oaks, CA: SAGE Publications Inc.

Hair, J.F., Ringle, C.M., \& Sarstedt, M. (2011). PLS-SEM: Indeed a silver bullet. Journal of Marketing Theory and Practice, 19(2), 139-152. http://dx.doi. org/10.2753/MTP1069-6679190202

Halachmi, A. (2002). Performance measurement: A look at some possible dysfunctions. Work Study, 51(5), 230-239. http://dx.doi.org/10.1108/ 00438020210437240

Halachmi, A. (2003). Governance and risk management: The challenge of accountability, transparency and social responsibility. International Review of Public Administration, 8(1), 67-76. http://dx.doi.org/10.1080/12294659.2 003.10805018

Hayne, C., \& Free, C. (2014). Hybridized professional groups and institutional work: COSO and the rise of enterprise risk management. Accounting, Organizations and Society, 39(5), 309-330. http://dx.doi.org/10.1016/j. aos.2014.05.002

Heilig, J.V., Young, M., \& Williams, A. (2012). At-risk student averse: Risk management and accountability. Journal of Educational Administration, 50(5), 562-585. http:/ / dx.doi.org/10.1108/09578231211249826

Henri, J-F. (2006a). Management control systems and strategy: A resource-based perspective. Accounting, Organizations and Society, 31(6), 529-558. http:// dx.doi.org/10.1016/j.aos.2005.07.001

Henri, J-F. (2006b). Organizational culture and performance measurement systems. Accounting, Organizations and Society, 31(1), 77-103. http://dx.doi. org/10.1016/j.aos.2004.10.003

Hooley, G., Broderick, A., \& Möller, K. (1998). Competitive positioning and the resource-based view of the firm. Journal of Strategic Marketing, 6(2), 97-116. http://dx.doi.org/10.1080/09652549800000003

Hoque, Z. (2008). Measuring and reporting public sector outputs/outcomes: Exploratory evidence from Australia. International Journal of Public Sector Management, 21(5), 468-493. http:/ / dx.doi.org/10.1108/09513550810885787

Hoyt, R.E., \& Liebenberg, A.P. (2011). The value of enterprise risk management. Journal of Risk and Insurance, 78(4), 795-822. http://dx.doi.org/10.1111/ j.1539-6975.2011.01413.x

Hudin, N.S., \& Hamid, A.B.A. (2014). Drivers to the implementation of risk management practices: A conceptual framework. Journal of Advanced Management Science, 2(3), 163-169. http://dx.doi.org/10.12720/joams.2.3. 163-169 
Israel, G.D. (1992). Determining sample size. Florida: University of Florida Cooperative Extension Service, Institute of Food and Agriculture Sciences.

Jarvis, C.B., MacKenzie, S.B., \& Podsakoff, P.M. (2003). A critical review of construct indicators and measurement model misspecification in marketing and consumer research. Journal of Consumer Research, 30(2), 199-218. http:/ / dx.doi.org/10.1086/376806

Khalfan, A.M. (2004). Information security considerations in IS/IT outsourcing projects: A descriptive case study of two sectors. International Journal of Information Management, 24(1), 29-42. http://dx.doi.org/10.1016/j. ijinfomgt.2003.12.001

Kloot, L. (2009). Performance measurement and accountability in an Australian fire service. International Journal of Public Sector Management, 22(2), 128-145. http:/ / dx.doi.org/10.1108/09513550910934538

Leung, F., \& Isaacs, F. (2008). Risk management in public sector research: approach and lessons learned at a national research organization. $R \mathcal{E} D$ Management, 38(5), 510-519. http://dx.doi.org/10.1111/j.1467-9310.2008. 00529.x

Liebenberg, A.P., \& Hoyt, R.E. (2003). The determinants of enterprise risk management: Evidence from the appointment of chief risk officers. Risk Management and Insurance Review, 6(1), 37-52. http://dx.doi.org/10.1111/ 1098-1616.00019

Linsley, P.M., \& Lawrence, M.J. (2007). Risk reporting by the largest UK companies: readability and lack of obfuscation. Accounting, Auditing $\mathcal{E}$ Accountability Journal, 20(4), 620-627. http://dx.doi.org/10.1108/ 09513570710762601

Loosemore, M., Raftery, J., Reilly, C., \& Higgon, D. (2006). Risk management in projects. New York, NY: Taylor \& Francis.

MacBryde, J., Paton, S., Bayliss, M., \& Grant, N. (2014). Transformation in the defence sector: The critical role of performance measurement. Management Accounting Research, 25(2), 157-172. http://dx.doi.org/10.1016/j.mar.2013. 07.006

MacKenzie, S.B., Lee, J.Y., \& Podsakoff, N.P. (2003). Common method biases in behavioral research: A critical review of the literature and recommended remedies. Journal of Applied Psychology, 88(5), 879-903. http://dx.doi.org/ 10.1037/0021-9010.88.5.879

Manab, N.A., Bakar, A.A., \& Hussin, M.R. (2010). Enterprise-wide risk management (EWRM) practices: Between corporate governance compliance and value. International Review of Business Research Papers, 6(2), 239-252.

McShane, M.K., Nair, A., \& Rustambekov, E. (2011). Does enterprise risk management increase firm value? Journal of Accounting, Auditing $\mathcal{E}$ Finance, 26(4), 641-658. http:/ / dx.doi.org/10.1177/0148558X11409160

Merna, T., \& Al-Thani, F.F. (2005). Corporate risk management: An organisational perspective. Chichester, West Sussex: John Wiley \& Sons Ltd. 
Mikes, A. (2009). Risk management and calculative cultures. Management Accounting Research, 20(1), 18-40. http://dx.doi.org/10.1016/j.mar.2008. 10.005

Mikes, A., \& Kaplan, R.S. (2014). Towards a contingency theory of enterprise risk management (AAA 2014 Management Accounting Section (MAS) Meeting Paper). Retrieved from http:// dx.doi.org/10.2139/ssrn.2311293

Mintzberg, H., Raisinghani, D., \& Theoret, A. (1976). The structure of "unstructured" decision processes. Administrative Science Quarterly, 21(2), 246-275.

Mohamad, M.H.S., \& Ismail, S. (2014). The effect of regulation and goal orientation on performance measurement utilisation: Evidence from Indonesian local governments. Asian Journal of Business and Accounting, 7(1), 81-105.

Monetti, E., Rosa, S.A., \& Rocha, R.M. (2006, January). The practice of project risk management in government projects: A case study in Sao Paulo City. Paper presented at the Construction in Developing Economics: New Issues and Challenges Symposium, Santiago, Chile.

MS ISO 31000. (2010). Risk management - principle and guidelines. Department of Standards, Malaysia.

Mucciarone, M.A., \& Neilson, J. (2012). Performance reporting in the Malaysian Government. Asian Academy of Management Journal of Accounting and Finance, 7(2), 35-77.

National Audit Department. (2010). Auditor general's report 2010. Kuala Lumpur: Author.

National Audit Department. (2011). Auditor general's report 2011. Kuala Lumpur: Author.

National Audit Department. (2012). Auditor general's report 2012. Kuala Lumpur: Author.

National Audit Department. (2013). Auditor general's report 2013. Kuala Lumpur: Author.

National Audit Department. (2014). Auditor general's report 2014. Kuala Lumpur: Author.

Nisar, T.M. (2007). Risk management in public-private partnership contracts. Public Organization Review, 7(1), 1-19. http://dx.doi.org/10.1007/s11115006-0020-1

Nunnally, J.C. (1978). Psychometric theory. New York, USA: McGraw-Hill.

Nyland, K., \& Petterson, I.J. (2015). Hybrid controls and accountabilities in public sector management. International Journal of Public Sector Management, 28(2), 90-104. http:// dx.doi.org/10.1108/IJPSM-07-2014-0085

Paape, L., \& Speklé, R.F. (2012). The adoption and design of enterprise risk management practices: An empirical study. European Accounting Review, 21(3), 37-41. http:// dx.doi.org/10.1080/09638180.2012.661937

Pagach, D.P., \& Warr, R.S. (2010). The effects of enterprise risk management on firm performance (Working paper, North Carolina University). Retrieved from http://dx.doi.org/10.2139/ssrn.1155218 
Pagach, D., \& Warr, R. (2011). The characteristics of firms that hire chief risk officers. Journal of Risk and Insurance, 78(1), 185-211. http://dx.doi. org/10.1111/j.1539-6975.2010.01378.x

Palermo, T. (2014). Accountability and expertise in public sector risk management: a case study. Financial Accountability \& Management, 30(3), 322-341. http://dx.doi.org/10.1111/faam.12039

Parker, L.D., \& Gould, G. (1999). Changing public sector accountability: Critiquing new directions. Accounting Forum, 23(2), 109-135.

Preacher, K.J., \& Hayes, A.F. (2008). Asymptotic and resampling strategies for assessing and comparing indirect effects in multiple mediator models. Behavior Research Methods, 40(3), 879-891. http://dx.doi.org/10.3758/BRM. 40.3.879

Rahman, I.K.A., Ab Rahman, N.A., Azhar, Z., Omar, N., \& Said, J. (2015). Management accounting best practices award for improving corruption in public sector agencies. Procedia Economics and Finance, 31, 503-509. http:// dx.doi.org/10.1016/S2212-5671(15)01192-2

Rasid, S.Z.A., Golshan, N.M., Ismail, W.K.W., \& Ahmad, F.S. (2012, March). Risk management, performance measurement and organizational performance: A conceptual framework. Paper presented at the 3rd International Conference on Business and Economic Research (3rd ICBER), Bandung, Indonesia.

Roslan, A., \& Dahan, H.M. (2013a). Mediating effect of enterprise risk management on internal audit and organizational performance: A conceptual framework. International Journal of Commerce, Business and Management, 2(4), 212-215.

Roslan, A., \& Dahan, H.M. (2013b, June). Mediating effect of enterprise risk management practices on risk culture and organizational performance. Paper presented at the International Conference on Social Science Research, Penang, Malaysia.

Saeidi, P., Sofian, S., Rasid, S.Z.A., \& Saeid, S.P. (2012). The role of chief risk officer in adoption and implementation of enterprise risk management A literature review. International Research Journal of Finance and Economics, 88(April), 118-123.

Said, J., Abidin, N.A.Z., \& Nassir, N.M. (2014). Predictors of accountability outcomes in nonprofit organisations: An empirical investigation. Asia Pacific Management Accounting Journal, 8(2), 1-26.

Saliterer, I., \& Korac, S. (2013). Performance information use by politicians and public managers for internal control and external accountability purposes. Critical Perspectives on Accounting, 24(7-8), 502-517. http://dx.doi. org/10.1016/j.cpa.2013.08.001

Schillemans, T., Van Twist, M., \& Vanhommerig, I. (2013). Innovations in accountability: Learning through interactive, dynamic, and citizen-initiated forms of accountability. Public Performance \& Management Review, 36(3), 407-435. 
Shaoul, J., Stafford, A., \& Stapleton, P. (2012). Accountability and corporate governance of public private partnerships. Critical Perspectives on Accounting, 23(3), 213-229. http://dx.doi.org/10.1016/j.cpa.2011.12.006

Siddique, N.A. (2006). Pradoxes of Public Accountability in Malaysia: Control Mechanisms and Their Limitations. International Public Management Review, $7(2), 43-65$.

Simons, R. (1990). The role of management control systems in creating competitive advantage: New perspectives. Accounting, Organizations and Society, 15(1-2), 127-143. http:// dx.doi.org/10.1016/0361-3682(90)90018-P

Sinclair, A. (1995). The chameleon of accountability: Forms and discourses. Accounting, Organizations and Society, 20(2-3), 219-237. http://dx.doi.org/ 10.1016/0361-3682(93)E0003-Y

Sobel, P.J., \& Reding, K.F. (2004). Aligning corporate governance with enterprise risk management. Management Accounting Quarterly, 5(2), 29-38.

Söderholm, P., \& Norrbin, P. (2013). Risk-based dependability approach to maintenance performance measurement. Journal of Quality in Maintenance Engineering, 19(3), 316-329. http:/ / dx.doi.org/10.1108/JQME-05-2013-0023

Speklé, R.F., \& Verbeeten, F.H. (2014). The use of performance measurement systems in the public sector: effects on performance. Management Accounting Research, 25(2), 131-146. http://dx.doi.org/10.1016/j.mar.2013.07.004

Spira, L.F., \& Page, M. (2003). Risk management: The reinvention of internal control and the changing role of internal audit. Accounting, Auditing $\mathcal{E}$ Accountability Journal, 16(4), 640-661. http://dx.doi.org/10.1108/095135703 10492335

Stewart, J.D. (1984). The role of information in public accountability. In A. Hopwood \& C. Tomkins (Eds.), Issues in public sector accounting (pp. 13-34). Oxford: Philip Allen.

Subramaniam, N., Collier, P., Phang, M., \& Burke, G. (2011). The effects of perceived business uncertainty, external consultants and risk management on organisational outcomes. Journal of Accounting \& Organizational Change, 7(2), 132-157. http://dx.doi.org/10.1108/18325911111139671

Tan, X-X. (2014). Constructing a performance-based accountability system for the Chinese government. Journal of Public Affairs, 14(2), 154-163. http:// dx.doi.org/10.1002/pa.1519

Tang, C.S. (2006). Perspectives in supply chain risk management. International Journal of Production Economics, 103(2), 451-488. http://dx.doi.org/10.1016/ j.ijpe.2005.12.006

Queensland Treasury. (2011). A guide to risk management. The State of Queensland: Queensland Treasury.

Vandenbosch, B. (1999). An empirical analysis of the association between the use of executive support systems and perceived organizational competitiveness. Accounting, Organizations and Society, 24(1), 77-92. http://dx.doi. org/10.1016/S0361-3682(97)00064-0 
Wang, H., Barney, J.B., \& Reuer, J.J. (2003). Stimulating firm-specific investment through risk management. Long Range Planning, 36(1), 49-59. http://dx.doi. org/10.1016/S0024-6301(02)00203-0

Wernerfelt, B. (1984). A resource-based view of the firm. Strategic Management Journal, 5(2), 171-180. http://dx.doi.org/10.1002/smj.4250050207

Witthoft, G. (2003). Accountability and good governance in the public sector. Auditing SA, 22, 13-16.

Woods, M. (2008). Linking risk management to strategic controls: A case study of Tesco plc. International Journal of Risk Assessment and Management, 7(8), 1074-1088.

Woods, M. (2009). A contingency theory perspective on the risk management control system within Birmingham City Council. Management Accounting Research, 20(1), 69-81. http://dx.doi.org/10.1016/j.mar.2008.10.003 